\title{
Prosumerism and Post Covid-19 Malaysia Economic Recovery
}

\author{
Nasuha Mohamed Ridza* \\ Kulliyyah of Economics and Management Sciences \\ International Islamic University Malaysia \\ Kuala Lumpur, Malaysia \\ *nasuha176@yahoo.com
}

\author{
Mohamed Ridza Wahiddin \\ Cybersecurity \& Systems Unit, Islamic Science Institute \\ Universiti Sains Islam Malaysia \\ Negeri Sembilan, Malaysia \\ mridza@usim.edu.my
}

\begin{abstract}
COVID-19 pandemic had greatly affect many businesses and individuals in Malaysia. Therefore, this paper explores the possibility of applying the concept of prosumerism to help the economic growth of Malaysia post COVID-19. A prosumer is someone who consumes and at the same time produces goods or services. In this high-tech era, almost everything is at our fingertips and can be done from the comfort of our homes. Technology and the flexibility to work anywhere, are the essences of prosumerism which also correspond to the new normal of staying safe at home post COVID-19. Additionally, prosumerism promotes altruism which can be translated into learn more, produce more, share more in a society. Prosumerism promotes innovation, creativity and cooperation amongst economic agents which enable society to solve problems especially ones that are related to economic growth, in a cost-effective way.
\end{abstract}

Keywords-prosumerism, knowledge sharing, cooperation, economic growth

\section{INTRODUCTION}

World Health Organization (WHO) defines COVID-19 as an infectious disease caused by a newly discovered strain of coronavirus; a type of virus known to cause respiratory infections in humans. This dangerous disease was only made known worldwide in December 2019, after an outbreak of unidentified pneumonia cases emerged in Wuhan, China. Currently, COVID-19 is considered as a global pandemic affecting many countries [1]. This is because COVID-19 is highly contagious and can easily spread from one individual to another simply by shaking hands. Additionally, infected individuals may not have the energy and ability to work. Hence, deterring the economic growth of a country.

The first wave of infection started in Malaysia on 24 January 2020 with a total of 22 identified cases. 12 of the 22 identified cases had a travel history to affected countries and regions. The second wave began on 27 February 2020 and is still ongoing. As of 24 January 2021, there are 183,801 confirmed cases and 678 deaths due to COVID-19 recorded in Malaysia [2]. To prevent COVID-19 from infecting other healthy individuals, all infected individuals were isolated at designated hospitals or quarantine centers set by the Ministry of Health Malaysia (MOH).

Furthermore, a Movement Control Order (MCO) was imposed by the government of Malaysia on 18 March 2020 as a preventive measure to stop the spreading of COVID-19 in Malaysia. Under the MCO, only essential services such as electricity, health, safety, and retail could operate whilst all the other sectors were forced to close [3]. Consequently, Malaysia's economic condition deteriorated because businesses were not allowed to operate, and workers were forced to stay at home during the MCO. Prime Minister of Malaysia, Tan Sri Muhyiddin Yassin, said that for each day when business is suspended during MCO, Malaysia's economy is losing RM2.4 billion [4]. Thus, many workers lost their jobs due to retrenchment made by their employers.

However, the evolution of technology with better internet connection from before enables individuals to work from home whilst abiding the new normal of staying safe at home post COVID-19. In the same way, workers who are forced to be unemployed due to the poor economic condition post COVID19 may also earn income through online platforms. Both technological advance and earning income via online businesses are the cornerstones of prosumerism. Hence, this paper aims to study the role of prosumerism in Malaysia economic recovery post COVID-19.

\section{A. What is Prosumerism?}

An individual who consumes and at the same time produces goods or services is known as a prosumer. Alvin Toffler introduced the concept of prosumerism in his book titled The Third Wave, back in 1980. Prosumerism, according to Toffler happens when consumers or buyers become more involved in the production process via providing feedback and requesting product customization from the producers [5]. This will in turn increase consumers' rights and might solve the issue of bad services provided by the producers.

Knowledge sharing is the key to prosumerism. Nowadays, prosumers such as hobbyists like to share their creative processes online via YouTube. Thus, empowering other interested individuals to be able to learn how to make a specific 
item. For example, if we do not know how to bake cream puffs, instead of buying these from a bakery, we can learn how to do this simply by searching on the internet as lots of people who know how to make had shared online the recipe and steps to bake them. Furthermore, knowledge sharing by prosumers has become an important determinant in promoting innovation in the creation of goods and services [6].

International superstar, Justin Bieber, and local singer, Najwa Latif, both became popular through the process of prosumerism. Instead of just streaming music videos on YouTube, they both decided to upload their own songs and covers through the same platform and caught the attention of many people. Hence, earning them contracts from music labels. Here, we can see social media platforms have opened opportunities for amateurs to create, share and possibly obtain profits from their creative and innovative ideas without going through auditions or other preliminaries set by the industries or major companies. The use of social media platforms as an outlet for prosumers to promote themselves is possible due to the improved internet condition and speed in this modern world [7].

There are many benefits that prosumers can offer during this COVID-19 pandemic. For example, when countries implemented lockdowns and the society is no longer free to physically socialize and mingle with each other, there is an upsurge in prosumer activities of crafting, journaling, and cooking. These prosumers will then share their process and final products on social media platforms for others to see and learn from it [8]. Therefore, other individuals can now spend their time meaningfully during the lockdowns. Additionally, the knowledge sharing between prosumers via social media platforms can also help improve the mood of those who suffer from depression and anxiety caused by the lockdowns and uncertainties brought upon by the COVID-19 pandemic.

\section{B. Relationship between Prosumerism and Economic Recovery}

Through the advent of technology, it is now easy for people to access information as well as share information online. Online social platforms also play a vital role in allowing people across the globe to connect with each other. Presently, the internet has made it possible for consumers to become prosumers. Furthermore, the internet had become a platform for individuals to advertise their goods and services as it can reach a wider audience compared to that of traditional advertisements such as brochures and billboards.

Therefore, many individuals become more interested in online businesses also known as e-commerce. University students and even full-time employees are mainly involved in e-commerce to earn extra income as well as increase their savings. Examples of goods and services sold by these individuals are makeups, homemade desserts and some even offered delivery services such as GrabFood and Foodpanda. Thus, e-commerce sector that comes together with prosumerism might help recover Malaysia's economic condition post COVID-19.

\section{Methodology}

This is a pilot study based on many articles and journals reviewed. There are many factors influencing the economic recovery of a country. However, the writing of this paper is guided by the hypothesis that prosumerism is a catalyst for Malaysia economic recovery post COVID-19. The supporting evidence and facts obtained through the review of articles and journals may be competing or complementing each other. Nevertheless, this paper only reports on the role of prosumerism as hypothesized above. Furthermore, the review of articles and journals covered the key concepts of prosumerism that will help to strengthen Malaysia's economic growth post COVID-19.

Prosumers are defined as individuals who consumes goods and at the same time can produce it too. These individuals choose to share their knowledge of the goods rather than passively consuming it [9]. Through the idea of sharing, more individuals can produce the same type of goods and thus, number of sellers in a market will increase. Al-Zarqa suggested that many sellers in a market may lead the market to have an ideal competitive price and quantity of goods [10] Additionally, Ledvina and Sircar, agreed with this concept by providing an example how a monopoly became a duopoly with just an addition of one seller into the market. Thus, removing the exclusive right the previous seller had in determining the price of goods sold [11]

The act of sharing knowledge of how to produce and sell goods among prosumers is related to the act of selflessness and the ability of them to interact with one another as well as with potential buyers in the market. Selflessness means the prosumers are not scared of the fact that the number of their competitors might increase due to the knowledge sharing process. On the other hand, the ability to interact means that there are communications amongst the prosumers themselves as well as between the prosumers and potential buyers of their goods. The prosumers are also easily reachable via common social media platforms such as Instagram and Twitter. Moreover, a research conducted on prosumers living in Poland and the United Kingdom revealed that they are tech-savvy [12]. Therefore, prosumers are well-versed in using social media platforms.

Research done on profit-making companies in Indonesia shows that interaction ability and altruism are significantly correlated on the level of knowledge sharing participation among the surveyed workers [13]. Although the research has a large sample of respondents divided into broadcasting, banking, and services sectors, it was limited to only profitmaking companies. Therefore, it is not clear whether interaction ability and altruism are also significantly correlated to the participation level of knowledge sharing in the case of non-profit organizations. Furthermore, the research was also conducted on companies in only one province in Indonesia which is Riau. Therefore, the same results may not be applicable to companies located in other provinces. 
Notwithstanding the limitations of the study, its results still supports the idea of knowledge sharing being manifested by the selfless act of prosumers and ease of communication that comes together with prosumerism. Increase in knowledge sharing with everyone will further help individuals especially workers who were laid off due to COVID-19 to be creative in developing ways to generate income. Therefore, there might be a rise in online businesses which in turn will contribute to Malaysia economic recovery post COVID-19.

Afterwards, the results obtained from reviewing the articles and journals are analyzed and discussed. The relationship between prosumerism, e-commerce and Malaysia economic recovery are particularly highlighted in the next section.

\section{RESULTS AND DISCUSSIONS}

\section{A. Unemployment Rate in Malaysia Post COVID-19}

Economic growth and unemployment rate are two macroeconomic variables that can be used to measure the success of a country's economy [14]. Economic growth is defined as the increase of production of goods and services of a country. It is usually measured either by Gross Domestic Product (GDP) or Gross National Product (GNP). On the other hand, unemployment rate is defined as the percentage of unemployed workers in the total labor force. According to the United States (US) Bureau of Labor Statistics (BLS), when labors became unemployed, their household consumption will decrease as they lost their source of income to buy goods and services. As the demand for goods and services for these unemployed labors fall, other available labors may possibly be retrenched by their employers as only a small amount of workforce is needed to produce the decreased amount of goods and services [15]

The June 2020 Global Economic Prospects published by World Bank gives us a general outlook on how COVID-19 affects economic growth of a country in the long-run. World Bank predicts a $5.2 \%$ contraction in global GDP in 2020 although governments of respective countries tried to minimize the impacts of COVID-19 on their economic growth by introducing fiscal and monetary policy support. Furthermore, if the effects of COVID-19 on economic growth are not dealt swiftly, countries may experience an increase in unemployment rate and a decrease in the production of goods and services which will then lead to lower investment by investors [16].

After MCO was imposed by Malaysia's government in March 2020, the country's unemployment rate had increased to 5.3\% in May 2020 from 5\% in April 2020. In addition to this, the number of unemployed individuals in Malaysia post MCO was 826,100 [17]. This is because many businesses suffered serious losses as they were forced to close when MCO were implemented. Although the economic growth of Malaysia was greatly hampered by the implementation of $\mathrm{MCO}$, the decision made by the government of Malaysia was deemed necessary to curb the spreading of COVID-19 in Malaysia as many individuals were behaving irresponsibly. These irresponsible individuals did not adhere to the guidelines set by Malaysia's government on social distancing. Hence, resulting in an increase in the transmission of COVID-19 in the society [18]. Even during the MCO, there were many individuals that went against the outlined Standard Operating Procedures (SOP) which resulted in prolong period of MCO.

Prolong period of MCO or lockdown is not good for Malaysia as well as for other countries. This is because businesses and firms, regardless big or small, may not be able to overcome the losses incurred during the $\mathrm{MCO}$ or lockdown period. Moreover, since the world was caught off-guard with the COVID-19 pandemic, economic agents of a country were unprepared to face a long period of lockdown where most economic activities are forced to close. Micro, small and medium-sized enterprises (MSMEs) will be the one to suffer major losses during the COVID-19 pandemic as evidenced in a study done in Pakistan [19].

Malaysia is not the only country that suffers from an increase in the unemployment rate caused by the COVID-19 pandemic. A study forecasted that the unemployment rate in Italy, France, Belgium, Spain, and Germany will continue to rise as an effect of the COVID-19 pandemic which is still an ongoing global issue. Furthermore, the study also predicted that it would take at least five years for economic growth of these European countries to recover [20]. Hence, Malaysia's economic conditions and unemployment rate might also take five years or longer to recover.

\section{B. Prosumerism, E-Commerce and Malaysia Economic Recovery}

In 2018, Malaysia International Trade and Industry Deputy Minister said that e-commerce contribution to Malaysia's GDP had increased to $6.1 \%$ or RM74.6 billion in 2016 compared to $5.9 \%$ or RM68.3 billion in 2015 . Hence, to further support the e-commerce sector's continuous growth, Malaysia's government has implemented the National E-Commerce Strategic (NESR) Plan since October 2017. The government of Malaysia predicted the plan will help to double the e-commerce growth rate in Malaysia from $10.8 \%$ in 2016 to $20.8 \%$ by 2020 [21].

Malaysia's e-commerce transactions in 2017 was RM447.8 billion which is higher compared to RM398.2 billion in 2015 . Furthermore, the percentage of individuals using the internet in Malaysia had increased from $71.1 \%$ in 2015 to $80.1 \%$ in 2017. Moreover, internet usage in Malaysia's urban area also showed an increase from $76.3 \%$ in 2015 to $84.0 \%$ in 2017 . Additionally, the internet usage in Malaysia's rural area also increased from $55.0 \%$ in 2015 to $68.0 \%$ in 2017 [22]. Based on these statistics, it can be concluded that the increase of ecommerce transactions in Malaysia is in tandem to the increase of internet usage by the citizens of Malaysia. Therefore, it is possible for online businesses to become one of the preferred means by Malaysians to generate income especially during the current COVID-19 pandemic. 
A study done by Harvard Business School emphasized that the internet is used for online banking, checking news and weather forecasts. Subsequently, the study also highlighted the success of online businesses and how it helps the economy through innovation, knowledge sharing and jobs creation [23]. Thus, results of the study support the notion of this paper, that is, prosumerism will help economic condition in Malaysia to recover post COVID-19 through knowledge sharing and innovation which brings about the rise of online businesses.

\section{Suggestions for Economic Policymakers in Malaysia}

The concept of prosumerism is no longer strange in this era where technology is rapidly evolving every day. Currently, we can see how the internet is changing the way we work and socialize, especially after the COVID-19 pandemic. Additionally, the internet has also made it easy for knowledge and information to be shared around the globe.

Hence, government and policymakers of a country should acknowledge the immense prospects the internet can create by encouraging the development of a healthy internet ecosystem that will help owners of small online businesses flourish. Subsequently, these elements can help maximize the impact of the internet on economic growth of a country [24].

Apart from that, economic policymakers in Malaysia should consider offering courses related to arts, soft skills, computing skills, basic investment skills and other skill-related courses to the public. Moreover, these courses should either be free or only cost the public a minimum amount of registration fee. Furthermore, unemployed workers that could not join the labor force due to the ripple effect of COVID-19 should be the targeted participants of these courses. This is because if this group of unemployed workers can learn a new skill that are compatible with them, they might be able to start a small business by offering their skills. In other words, they too, will be able to contribute to the economic growth of Malaysia by offering their newly learned talents or skills.

A study made in South Africa, showed that the high rate of unemployment in the country during the period of study was because of insufficient amount of education provided to its denizens. Therefore, the study had highlighted the need for having skills training programs in South Africa to reduce its unemployment rate [25]. Hence, it is important for a country to provide skill-related courses as part of its social obligation to preserve the welfare of its citizens.

\section{CONCLUSION}

This pilot study had highlighted the impact of knowledge sharing which is the key takeaway of prosumerism. Subsequently, knowledge sharing will generate product innovation and with the rise of technology, individuals can now generate income from the comfort of their homes by engaging in online businesses. Hence, Malaysia economic recovery can be achieved through the rise of prosumers which in turn increases the number of online businesses in the country. Statistics provided in this paper also showed e-commerce in
Malaysia is contributing significantly towards the country's GDP. In addition, this paper also recommended economic policymakers in Malaysia to tackle the issue of unemployed labors that lost their jobs due to the impact of COVID-19 on businesses, by offering skill-related courses to these individuals. By cultivating new skills, these individuals will be able to produce goods and services in the market too. Consequently, contributing towards Malaysia economic recovery apart from generating income to sustain their living expenses.

\section{REFERENCES}

[1] Coronavirus disease (COVID-19) in Malaysia [Internet]. Who.int. 2020 [cited 11 August 2020]. Available from: https://www.who.int/malaysia/emergencies/coronavirus-disease-(covid19)-in-malaysia

[2] COVID-19 in Malaysia Situation Report 30 [Internet]. Who.int. 2021 [cited 7 February 2021]. Available from: https://www.who.int/malaysia/internal-publications-detail/covid-19-inmalaysia-situation-report-30. World Health Organization (WHO) COVID-19 SITUATION OVERVIEW IN MALAYSIA. World Health Organization (WHO); 2020.

[3] New Straits Times. Covid-19: Movement Control Order imposed with only essential sectors operating. [Internet]. 2020 [cited 9 August 2020]; Available https://www.nst.com.my/news/nation/2020/03/575177/covid-19movement-control-order-imposed-only-essential-sectors-operating

[4] Timbuong J. Our economy loses RM2.4bil every day MCO is active says PM. TheStar [Internet]. 2020 [cited 9 August 2020];: Available from: https://www.thestar.com.my/news/nation/2020/04/25/oureconomy-loses-rm24bil-every-day-mco-is-active-says-pm

[5] Alderete M. The Age of Prosumerism: Some Micro-Economic Analysis. Journal of Theoretical and Applied Electronic Commerce Research 2017;12(3):1-12.

[6] Ziemba E, Eisenbardt M. The Ways of Prosumers' Knowledge Sharing with Organizations. Interdisciplinary Journal of Information, Knowledge, and Management. 2018;13:95-115.

[7] Dusi D. The Perks and Downsides of Being a Digital Prosumer: Optimistic and Pessimistic Approaches to Digital Prosumption International Journal of Social Science and Humanity. 2016;6(5):375381.

[8] Lang B, Dolan R, Kemper J, Northey G. Prosumers in times of crisis: definition, archetypes and implications. Journal of Service Management. 2020 .

[9] Marsden C. Prosumer law and network platform regulation: the long view towards creating OffData. Georgetown Law Technology Review. 2018;2(2):376-398.

[10] Kahf M. Encyclopaedia of Islamic Economics. 2nd ed. London: Encyclopaedia of Islamic Economics; 2009.

[11] Ledvina A, Sircar R. Dynamic Bertrand and Cournot Competition: Asymptotic and Computational Analysis of Product Differentiation. SSRN Electronic Journal. 2011.

[12] Ziemba E, Eisenbardt M, Mullins R, Grabara D. Prosumers knowledge sharing to develop and manage products. Online Journal of Applied Knowledge Management. 2018;6(2):72-91.

[13] Saide S, Astuti E, Indrajit R, Trialih R, Diniaty A, Dewi F et al. What we give, we get back - Investigating the dimensions that influence knowledge sharing on profit enterprise in Indonesia. Journal of Science and Technology Policy Management. 2019;10(5):1047-1062.

[14] Soylu Ö, Çakmak İ, Okur F. Economic growth and unemployment issue: Panel data analysis in Eastern European Countries. Journal of International Studies. 2018;11(1):93-107. 
[15] Picardo E. How the Unemployment Rate Affects Everybody [Internet]. Investopedia. 2020 [cited 3 August 2020]. Available from: https://www.investopedia.com/articles/economics/10/unemploymentrate-get-real.asp

[16] The Global Economic Outlook During the COVID-19 Pandemic: A Changed World [Internet]. World Bank. 2020 [cited 7 August 2020]. Available from:

https://www.worldbank.org/en/news/feature/2020/06/08/the-globaleconomic-outlook-during-the-covid-19-pandemic-a-changed-world

[17] Chandran Shankar A. Malaysia unemployment rate escalates to $5.3 \%$ in May. The Edge Markets [Internet]. 2020 [cited 6 August 2020]; Available from: https://www.theedgemarkets.com/article/malaysiaunemployment-rate-escalates-53-may

[18] Goenka A, Liu L, Nguyen M. Infectious diseases and economic growth. Journal of Mathematical Economics. 2014;50:34-53.

[19] Shafi M, Liu J, Ren W. Impact of COVID-19 pandemic on micro, small, and medium-sizedEnterprises operating in Pakistan. Research in Globalization. 2020;2:1-14.
[20] Ahmad M, Khan Y, Jiang C, Kazmi S, Abbas S. The impact of COVID-19 on unemployment rate: An intelligent based unemployment rate prediction in selected countries of Europe. International Journal of Finance \& Economics. 2021:1-16.

[21] New Straits Times. E-commerce growth has been significant in Malaysia. [Internet]. 2018 [cited 5 August 2020];. Available from: https://www.nst.com.my/business/2018/03/345053/e-commerce-growthhas-been-significant-malaysia

[22] Mat H, Ya'akub M. E-Commerce: The Contribution to the Malaysia's Economy. Asia-Pacific Economic Statistics Week. Bangkok: Regional Programme in Asia-Pacific Economic Statistics; 2019. p. 2-11.

[23] Imansyah R. Impact of Internet Penetration for the Economic Growth of Indonesia. Evergreen. 2018;5(2):36-43.

[24] Manyika J, Roxburgh C. The great transformer: The impact of the Internet on economic growth and prosperity. Mckinsey Global Institute. 2011:1-9.

[25] Tshabalala N. Crime and Unemployment in South Africa; Revisiting an Established Causality: Evidence from the Kwazulu Natal Province. Mediterranean Journal of Social Sciences. 2014;5(15):519-528 